\title{
FACULTY BUY-IN AND THE BOTTOM-UP APPROACH: A CASE STUDY IN INTEGRATED ENGINEERING CURRICULUM REFORM ADVOCACY AND EWB'S GLOBAL ENGINEERING PROGRAM
}

\author{
Sal Alajek, B.Eng. Society, Global Engineering Team Lead \\ Engineers Without Borders Canada \\ Global Engineering Program
}

\begin{abstract}
A recent Perdue University study identified faculty buy-in as the primary obstacle for engineering curriculum reform in North America. Delegates at the recent 2012 Engineers Without Borders (EWB) Global Engineering Symposium agreed, indicating it is one of the major challenges facing Canadian engineering education institutions today. For over 8 years, EWB Canada has been advocating for Global Engineer-focused education, successfully collaborating with faculty at over 20 Canadian, post-secondary institutions to promote these concepts skills and attitudes to thousands of engineering students. This paper describes the evolution of EWB's approach to curriculum reform advocacy, which now focuses on building faculty relationships, student driven innovation, and incentivizing cooperation. This bottom-up strategy appropriately addresses the challenges of faculty buyin by promoting integrated curricular and extra-curricular education, which conforms to, but is not limited by, the CEAB attributes.
\end{abstract}

